\title{
Hubungan Pola Asuh Orangtua dengan Motivasi Belajar Remaja
}

\author{
Cindy Marisa ${ }^{1 *)}$, Evi Firtiyanti ${ }^{2}$, Sri Utami $^{3}$ \\ ${ }^{123}$ Universitas Indraprasta PGRI \\ $\equiv$ e-mail: cindy.marisa@unindra.ac.id
}

\begin{abstract}
Abstrack
This research is based on parents' thinking is an important learning motivator for children, including in adolescence, because the family is the first and main environment. Provision of appropriate parenting patterns should also follow a good child's learning motivation. This study aims to determine whether there is a significant positive relationship between the pattern of care with motivation in learning, and knowing where old parenting patterns have the motivation to learn. The research design used herein is correlative with the method. Data taken by using closed questionnaires. Data were analyzed using Spearman's rho test. With this method researchers collect as much data as possible about the dimensions of motivation to learn, then do the analysis of these dimensions to get the complete data and as objective as possible with the pattern of care and motivation to learn adolescents. Testing is done by $t$ test. Based on the data analysis can be concluded there is a significant relationship between the pattern of care with adolescent learning motivation with a contribution of $18.8 \%$, where again increased adolescent learning motivation caused by other factors.
\end{abstract}

Keyword: parenting parent, motivation to learn

Copyright (C) 2018 IICET (Indonesia) - All Rights Reserved

Indonesian Institute for Counseling, Education and Therapy (IICET)

\section{PENDAHULUAN}

Keberhasilan seseorang dalam kehidupannya tidak terlepas dari peran keluarga, baik orangtua maupun anggota keluarga lainnya. Keluarga merupakan akses terdekat dalam aktivitas kehidupan seseorang. Komunikasi yang terjalin dengan baik mampu memberikan dukungan positif bagi keberhasilan anggota keluarga yang satu dan lainya. Dukungan positif dapat memperkuat motivasi seseorang dalam mencapai keberhasilan tersebut.

Dukungan positif yang diberikan keluarga dan anggota lainnya dapat dikatakan motivasi eksternal. Dukungan positif keluarga dalam memotivasi dapat berbentuk verbal dan nonverbal, juga dapat berbentuk fisik (kebendaan).Menurut Hamzah B. Uno (2012:34) teknik motivasi yang dapat dilakukan dalam pembelajaran sebagai berikut: "pernyataan penghargaan secara verbal, menggunakan nilai ulangan sebagai pemacu keberhasilan, menimbulkan rasa ingin tahu, memunculkan sesuatu yang tidak diduga oleh siswa".

Orangtua bertanggung jawab terhadap anak dalam hal asih, asah, dan asuh. Asih yakni orangtua memberikan kasih sayang terhadap anaknya. Asah yakni orangtua mengeksporasi kemampuan anak sesuai bakatnya. Dan Asuh yakni orangtua mendidik anak sehingga memiliki perilaku yang sesuai dengan tingkat perkembangannya. Pola asuh yang sesuai dengan kebutuhan anak, akan memungkinkan dukungan positif 
diterima oleh anak tersebut. Pola asuh orang tua merupakan interaksi antara orangtua dan anak dalam berkomunikasi, mendidik, mengasuh, dan terus berkelanjutan dari waktu kewaktu. "Dengan pola asuh yang diterapkan orang tua anak dapat berinteraksi dengan lingkungan mengenai dunia sekitar serta mengenal pergaulan hidup yang berlaku dilingkungannya"(Israfil, 2015).

E.B. Hurlock (2012:206) "awal masa remaja berlangsung kira-kira dari tiga belas tahun sampai enam belas atau tujuh belas tahun, dan akhir masa remaja bermula dari usia 16 atau 17 tahun sampai delapan belas tahun, yakni usia matang secara hukum". Dengan demikian masa remaja masih dalam proses pengasuhan orangtua. Terkait dengan motivasi belajarnya, orangtua masih mungkin memiliki peranan penting dalam memberikan dukungan positif melalui pola asuh yang sesuai.

Hurlock (2012: 221) menyatakan faktor-faktor yang mempengaruhi sikap remaja terhadap pendidikan, antara lain:

1. Sikap teman sebaya : berorientasi atau berorientasi kerja.

2. Sikap orang tua : menggangap pendidikan sebagai bantu loncatan kearah sekolah : mobilitasi sosial atau hanya sebagai suatu kewajiban karena diharuskan oleh hukum.

3. Nilai nilai yang menunjukan keberhasilan atau kegagalan akademis.

4. Relevansi atau nilai praktis dari berbagai nilai mata pelajaran.

5. Sikap terhadap buru-buru, pegawai tata usaha, dan kebijaksanaan akademia serta disiplin.

6. Keberhasilan dalam pelbagai kegiatan ektra kurikuler.

7. Derajat dukungan sosial diantara teman-teman sekelas.

Menurut Purwanto (2007: 71) motivasi adalah "pendorong" suatuusaha yang disadari untuk mempengaruhi tingkah laku seseorang agar ia tergerak hatinya untuk bertindak melakukan sesuatu sehingga mencapaihasil atau tujuan tertentu.

Motivasi sangat penting dalam proses pengajaran dan pembelajaran kerana ia dapat menentukan hala tuju dan keberkesanannya. Pelajar yang bermotivasi tinggi biasanya mempunyai dorongan yang kuat dan mantap untuk terus berminat dengan apa yang disampaikan hasil dari rangsangan-rangsangan yang kuat iaitu menerusi insentif dan motif. Insentif dalam pengajaran dan pembelajaran sering disampaikan dalam bentuk ekstrinsik seperti markah, gred, wang, pujian, penghargaan, tanda bintang dan sebagainya. Motif pula timbul akibat dorongan semula jadiatau kecenderungan individu yang menggerakkanindividu untuk bertindak bagi mencapai sesuatu matlamat walaupun dalam tempoh yang lama.(Nasir \& Hamzah, 2014)

"Motivasi dan belajar merupakan dua hal yang saling mempengaruhi. Belajar adalah perubahan tingkah laku secara relatif permanen dan secara potensial terjadi sebagai hasil dari praktek atau penguatan (reinforced practice) yang dilandasi tujuan untuk mencapai tujuan tertentu". Lebih lanjut dinyatakan, "dalam kegiatan belajar motivasi dapat dikatakan sebagai keseluruhan daya pengerak di dalam diri siswa yang menimbulkan, menjamin kelangsungan dan memberikan arah kegiatan belajar, sehingga diharapkan tujuan dapat tercapai"(H. Uno, n.d.). Motivasi merupakan faktor penentu dan berfungsi menimbulkan, mendasari dan mengarahkan perbuatan belajar. Motivasi dapat menentukan baik tidaknya dalam mencapai tujuan sehingga semakin besar motivasinya akan semakin besar kesuksesan, tampak gigih, tidak mau menyerah, giat belajar untuk meningkatkan prestasi belajarnya. (Miru, 2009)

Fungsi motivasi menurut Sardiman A.M (2011:85) ada tiga fungsi, yaitu:

Mendorong manusia untuk berbuat, jadi sebagai penggerak atau motor yang melepaskan energi. Motivasi dalam hal ini merupakan motor penggerak dari setiap kegiatan yang akan dikerjakan. Menentukan arah perbuatan, yakni kearah tujuan yang hendak dicapai. Dengan demikian motivasi dapat memberikan arah dan kegiatan yang harus dikerjakan sesuai dengan rumusan tujuannya. Menyeleksi perbuatan, yakni menentukan perbuatan-perbuatan apa yang harus dikerjakan yang serasi guna mencapai tujuan, dengan menyisihkan perbuatan-perbuatan yang tidak bermanfaat bagi tujuan tersebut. Seseorang siswa akan menghadapi ujian dengan harapan lulus, tentu akan melakukan kegiatan belajar dan tidak akan menghabiskan waktunya untuk bermain kartu atau membaca komik, sebab tidak serasi dengan tujuan. 
Santrock (2010:514) menyatakan "motivasi dilihat dari sifatnya yakni motivasi intrinsik. Motivasi intrinsik adalah motivasi internal untuk melakukan sesuatu demi sesuatu itu sendiri (tujuan itu sendiri). Sedangkan motivasi lainnya adalah motivasi ekstrinsik. Motivasi ekstrinsik adalah dorongan terhadap perilaku seseorang yang ada diluar perbuatan yang dilakukannya".Beberapa teknik motivasi yang dapat dilakukan dalam pembelajaran sebagai berikut:

Pernyataan penghargaan secara verbal, Menggunakan nilai ulangan sebagai pemacu keberhasilan, Menimbulkan rasa ingin tahu, Memunculkan sesuatu yang tidak diduga oleh siswa, Menjadikan tahap dini dalam belajar mudah bagi siswa, Menggunakan materi yang dikenal siswa sebagai contoh dalam belajar, Gunakan kaitan yang unik dan tak terduga untuk menerapkan suatu konsep dan prinsip yang telah dipahami, Menuntut siswa untuk menggunakan hal-hal yang talah dipelajari sebelumnya, Menggunakan simulasi dan permainan, Memberikan kesempatan kepada siswa untuk memperlihatkan kemahirannya di depan umum, Mengurangi akibat yang tidak menyenangkan dan keterlibatan siswa dalam kegiatan belajar, Memahami iklim sosial dalam sekolah, Memanfaatkan kewibawaan guru secara tepat, Memperpadukan motif-motif yang kuat, Memperjelas tujuan belajar yang hendak di capai, Merumuskan tujuan-tujuan sementara, Memberitahukan hasil kerja yang telah dicapai, Membuat suasana persaingan yang sehat di antara para siswa, Mengembangkan persaingan dengan diri sendiri, dan Memberikan contoh yang positif.(H. Uno, n.d.)

\section{Menurut Sri Esti (2006:330) :}

Siswa yang telah di-reinforced atau diperkuat untuk belajar (contoh, dengan memberi nilai bagus atau pujian dari orang tua atau gurunya) akan "bermotivasi" untuk belajar, tetapi siswa-siswi yang tidak diperkuat untuk belajar, karena orang tua atau gurunya tidak memuji belajarnya tidak akan "termotivasi" untuk belajar. Demikian juga siswa yang telah dihukum dalam belajarnya, misal karena mendapat nilai ulangan harian jelek, mungkin tidak lagi ber-"motivasi” untuk belajar.

Ladeni J (2012: 81-86) menyatakan:

Motivasi siswa meningkat diakibatkan sebagai berikut: (1) siswa menemukan secara mandiri konsep materi yang diberikan; (2) siswa diberi kesempatan untuk mengungkapkan ide yang mereka miliki. (3) ada lingkungan belajar yang kondusif; (4) siswa diberikan kesempatan untuk mendiskusikan konsep yang mereka kurang pahami dengan teman kelompok.

Niaraki (2013) menjelaskan "Penelitian yang telah dilakukan dalam beberapa tahun terakhir, pada remaja di Iran tahun 2012 didapati bahwa pola asuh orang tua mempengaruhi kesehatan mental, harga diri dan kualitas hidup anak".Selain itu, Kordi (2010) menjelaskan "penelitian yang dilakukan di Malaysia pada tahun 2010 juga mendapati adanya bahwa pola asuh orang tua mempengaruhi prestasi anak".

Djamarah (2014 : 51) menyatakan "pola asuh orangtua adalah upaya orangtua yang konsisten dan persisitent yang diterapkan pada anak dan bersifat tetap dari waktu kewaktu. Pola asuh orangtua berarti kebiasaan orangtua dalam memimpin, mengasuh, dan membimbing anak dalam sebuah keluarga".

Musaheri (2007: 133) berpendapat "Pola asuh atau mengasuh anak adalah semua aktivitas orang tua yang berkaitan dengan pertumbuhan fisik dan otak. Apabila pola asuh orang tua yang diberikan orang tua kepada anak salah maka akan berdampak pada kepribadian anak itu sendiri”.

Diane Baumrind (dalam Sri Esti, 2006: 77-78) :

Meneliti gaya atau cara orang tua dalam mendidik anak-anaknya. Dia mengidentifikasikan tiga cara orang tua yang bervariasi, meliputi tingkat kontrol orang tua terhadap anak, kejelasan komunikasi orang tua dan anak dan tuntutan orang tua kepada anak untuk menjadi matang. Cara mendidik anak tersebut yaitu orang tua yang otoriter (authoritarian parents), orang tua yang membiarkan (permissive), dan orang tua dapat dipercaya (authoritative).

"Para peneliti yang mempelajari reaksi orang tua terhadap anak-anaknya menemukan ada tiga gaya umum dalam menjalankan peranannya sebagai orang tua yaitu otoriter, permisif, dan otoritatif'(H. B. Uno, 2006). 
Pengasuhan otoriter (authoritarian parenting) adalah suatu gaya pengasuhan yang membatasi dan menuntut anak untuk mengikuti perintah-perintah orang tua. Orang tua yang otoriter biasanya memiliki sikap yang "acceptance" rendah namun kontrolnya tinggi, suka menghukum secara fisik, bersikap mengomando (mengharuskan/memerintah anak untuk melakukan sesuat tanpa kompromi), bersikap kaku dan cenderung emosional dan bersikap menolak.(Yusuf, n.d.)

"Orang tua yang memberikan kebebasan sebanyak mungkin kepada anak mereka dan menempatkan harapan-harapan kepada anak mereka. Orang tua yang permisif ini sikap "acceptance"-nya tinggi namun kontrolnya rendah, serta memberi kebebasan kepada anak untuk menyatakan dorongan/keinginannya". (Yusuf, n.d.)

Mulyani dan Nana (2007: 247-248) menyatakan tindakan orang tua agar anaknya termotivasi dan berhasil mengikuti pendidikan di sekolah antara lain:

1. Mereka membaca, berbicara dan mendengarkan pada anaknya, mereka menceritakan perihal anaknya, bermain bersama, bersama-sama melakukan hobi, dan mendiskusikan berbagai berita, program televisi dan kejadian-kejadian yang hangat (up to date).

2. Mereka menyediakan tempat belajar dan menyimpan buku-buku secara teratur.

3. Mereka mempersiapkan makanan pada waktu tertentu dengan tepat, tempat tidur, dan tempat mengerjakan PR dan berkeyakinan bahwa anaknya dapat mengikuti pelajaran di sekolah.

4. Mereka selalu mengawasi waktu anak-anak menonton televisi, program yang dilihat dan kegiatan anak setelah kembali dari sekolah.

5. Mereka menaruh perhatian tentang kehidupan anaknya di sekolah, cerita anaknya tentang kejadian di sekolah dan berbagai masalah yang timbul selama anaknya sekolah

\section{METODOLOGI}

Metode yang digunakan dalam penelitian ini adalah survei dengan teknik korelasional.Menurut Kerlinger (dalam Riduwan, 2004: 49) menyatakan bahwa"penelitian survei adalah penelitain yang dilakukan pada populasi besar atau kecil, tapi data yang diambil adalah data dari sampel yang diambil dari populasi tersebut, sehingga ditemukan kejadian-kejadian relative, distribusi dan hubungan antar variable sosiologis maupun psikologis". Sampel tersebut adalah sampel yang benar-benar mewakili populasi yang akan diteliti. Variabel penelitian ini yaitu variabel terikat (dependent variable) adalah Motivasi Belajar Remaja (Y) dan variabel bebas (independent variable) adalah Pola Asuh Orangtua(X). Menurut kerangka berpikir dan hipotesis penelitian diduga antara variabel bebas dan variabel terikat tersebut ada hubungan sebab akibat dan saling mengadakan perubahan. Untuk itu maka teknik analisis pembuktian hipotesis tersebut digunakan teknik korelasional. Rakhmat (2002: 27) mengungkapkan bahwa "metode korelasi bertujuan meneliti sejauh mana variasi pada satu faktor berkaitan dengan variasi pada faktor lain".Sumber data penelitian ini diperoleh melalui pengadministrasian aplikasi instrumentasi identifikasi masalah. Sedangkan, penetapan sampel atau sumber data dalam penelitian ini menggunakan teknik perposive sampel. Instrumen yang digunakan adalah skala likert yang disusun berdasarkan kisi-kisi yang telah dipersiapkan. Kemungkinan jawaban dibagi menjadi 5 rentangan masing-masing rentangan mempunyai skor. Instrumen yang disebar untuk mendapatkan informasi terkait pola asuh orangtua dan motivasi belajar remaja merupakan angket tertutup, yaitu dengan opsi pilihan jawaban yang sudah tersedia.

\section{HASIL DAN PEMBAHASAN}

Deskripsi data ini merupakan deskripsi data statistik dari hasil perhitungan atas penelitian yang dilakukan untuk mengukur dua variabel, yaitu Pola Asuh Orangtua (X) sebagai variabel bebas danMotivasi Belajar Remaja (Y) sebagai variabel terikat. 
Tabel1

Deskripsi Statstik Variabel Pola Asuh Orangtua dan Motivasi Belajar Remaja

\begin{tabular}{|c|c|c|c|}
\hline \multicolumn{4}{|c|}{ Statistics } \\
\hline & & Pola Asuh & Motivasi Belajar \\
\hline \multirow[t]{2}{*}{$\mathrm{N}$} & Valid & 21 & 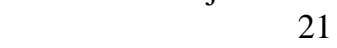 \\
\hline & Missing & 0 & 0 \\
\hline \multicolumn{2}{|c|}{ Mean } & 193.71 & 147.71 \\
\hline \multicolumn{2}{|c|}{ Median } & 194.00 & 144.00 \\
\hline \multicolumn{2}{|c|}{ Mode } & $193^{\mathrm{a}}$ & $137^{\mathrm{a}}$ \\
\hline \multicolumn{2}{|c|}{ Std. Deviation } & 10.345 & 13.004 \\
\hline \multicolumn{2}{|c|}{ Skewness } & -1.526 & .698 \\
\hline \multicolumn{2}{|c|}{ Std. Error of Skewness } & .501 & .501 \\
\hline \multicolumn{2}{|c|}{ Kurtosis } & 3.655 & -.455 \\
\hline \multicolumn{2}{|c|}{ Std. Error of Kurtosis } & .972 & .972 \\
\hline \multicolumn{2}{|c|}{ Range } & 46 & 47 \\
\hline \multicolumn{2}{|c|}{ Minimum } & 162 & 128 \\
\hline \multicolumn{2}{|c|}{ Maximum } & 208 & 175 \\
\hline
\end{tabular}

\section{Analisis Data Variabel Pola Asuh Orangtua (X) dan Variabel Motivasi Belajar Remaja (Y)}

Berdasarkan data di atasmenunjukkan perbedaan jawaban reponden termasuk tinggi. Hal ini menunjukkan bahwa pola asuh orangtua yang diterima responden sangat beragam. Dari deskripsi tersebut juga dapat dilihat bahwa antara nilai mean dan median hampir sama, yaitu 193,71 dan 194. Hal ini menunjukkan bahwa data skor pola asuh orangtua pada penelitian ini cukup representatif. Sedangkan histogram dari data tersebut bisa dilihat pada gambar 1 .

Data di atas juga menunjukkan bahwa motivasi belajar yang dimiliki responden tidak cukup beragam.Dari deskripsi tersebut juga dapat dilihat bahwa antara nilai mean dan median hampir sama, yaitu 147,71dan 144. Hal ini menunjukkan bahwa data skor motivasi belajar pada penelitian ini cukup representatif. Sedangkan histogram dari data tersebut bisa dilihat pada gambar 2 .

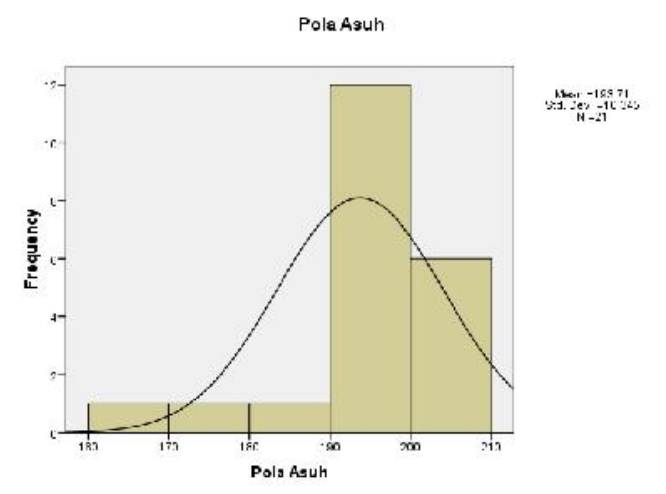

Gambar 1 Histogram Data Skor Pola Asuh Orangtua

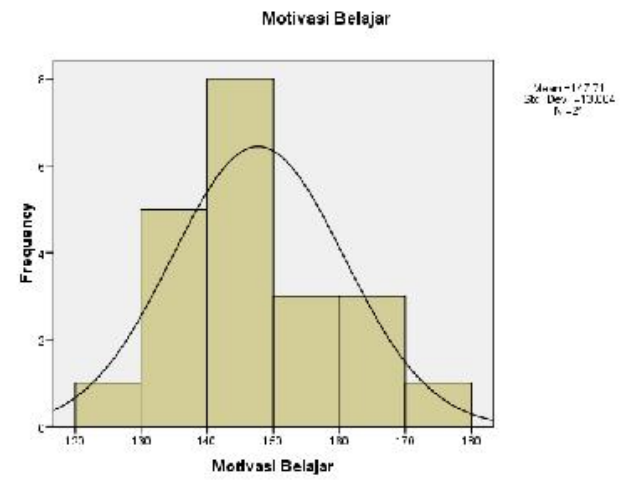

Gambar 2 Histogram Data Skor Motivasi

\section{Belajar}

\section{Pengujian Hipotesis Penelitian}

$\mathrm{H}_{0}$ : tidak terdapat hubungan Pola Asuh Orangtua (X) dengan Motivasi Belajar (Y).

$\mathrm{H}_{1}$ : terdapat hubungan Pola Asuh Orangtua (X) dengan Motivasi Belajar (Y). 
Table 4. Hasil Perhitungan Koefisien Korelasi

\section{Hubungan Variabel X dengan Y}

\begin{tabular}{|c|c|c|c|c|}
\hline \multicolumn{5}{|c|}{ Model Summary } \\
\hline Model & $\mathrm{R}$ & R Square & Adjusted R Square & Std. Error of the Estimate \\
\hline 1 & $.433^{\mathrm{a}}$ & .188 & .145 & 12.024 \\
\hline a. Pred & ant), Pola A & & & \\
\hline
\end{tabular}

\section{Tabel 5. Rekapitulasi Hasil Pengujian Signifikansi Koefisien Regresi Hubungan Variabel X dengan Y}

Berdasarkan Tabel 4 terlihat bahwa koefisien korelasi hubungan Pola Asuh Orangtua (X) dengan Motivasi Belajar (Y) adalah sebesar 0,433. Dengan kata lain bahwa terdapat hubungan Pola Asuh Orangtua (X) dengan Motivasi Belajar (Y). Sedangkan koefisien determinasinya adalah sebesar $18.8 \%$ menunjukkan bahwa pola asuh orangtua memberikan konribusi sebesar demikian, dan sisanya dipengaruhi oleh faktor lainnya.

Kemudian untuk pengujian hipotesis melalui analisis regrasi diperoleh hasil perhitungan terlihat pada table 5 diperoleh persamaan garis regrasi yang mempresentasikan hubungan variable $\mathrm{X}$ dengan $\mathrm{Y}$, yaitu $42,155+0,545 X$. Dan pengujian signifikansi garis regresi tersebut adalah dengan memperhatikan hasil perhitungan pada tabel 5. Terlihat bahwa nilai Sig. $=0,05$ dan thitung $=2,097>$ ttabel= 2,093. Dengan demikian maka H0 ditolak yang bearti bahwa koefisien tersebut signifikan. Berarti bahwa terdapat hubungan yang cukup signifikan variabel bebas pola asuh orangtua $(\mathrm{X})$ dengan variabel terikat motivasi belajar (Y).

\section{Pembahasan Penelitian}

Hasil penelitian menunjukkan bahwa terdapat hubungan antara pola asuh orangtua dan motivasi belajar. Jika dilihat dari nilat t0 statistik menunjukkan bahwa variabel layanan konseling dengan nilai t0 = 2,097 dan Sig. =0,05; ini menunjukkan bahwa pola asuh orangtua memiliki hubungan yang cukup signifikan dengan motivasi belajar anak. Selanjutnya persamaan regresi dapat dituliskan sebagai berikut :

$$
\hat{\mathrm{Y}}=42,155+0,545 \mathrm{X}^{*}
$$

Berdasarkan persamaan tersebut dapat dinarasikan sebagai berikut. Setiap kenaikan satu unit total skor pola asuh orangtua $(\mathrm{X})$ terdapat hubungan dengan kenaikan motivasi belajar (Y) sebesar 0.545 unit total skor motivasi belajar.

Menurut sintesis dari BAB II mengenai kajian teori, telah dijelaskan bahwa pola asuh orang tua merupakan segala perlakuan yang diberikan orang tua dalam memberikan didikan dan bimbingan dalam perkembangan kehidupan anak, baik dalam ranah pembentukkan kepribadian, kemampuan berhubungan sosial, kegiatan proses belajar, dan perencanaan karir untuk bekal di masa depan. Pla asuh yang diberikan sejak dini tentu membentuk kepribadian sang anak yang akan mempengaruhi segala sikap dan tindakannya terhadap apapun, termasuk kegiatan belajar. Misalnya, anak yang diberikan pola asuh otoritatif akan menjadi anak yang disiplin dan bertanggung jawab terhadap tugas, namun tetap mandiri dan kreatif. Sedangkan anak

\begin{tabular}{|c|c|c|c|c|c|c|}
\hline \multicolumn{7}{|c|}{ Coefficients $^{\mathbf{a}}$} \\
\hline \multirow{2}{*}{\multicolumn{2}{|c|}{ Model }} & Unstandardiz & oefficients & Standardized & $\mathrm{t}$ & Sig. \\
\hline & & B & Std. Error & Beta & & \\
\hline \multirow[t]{2}{*}{1} & (Constant) & 42.155 & 50.414 & & .836 & .413 \\
\hline & Pola Asuh & .545 & .260 & .433 & 2.097 & .050 \\
\hline \multicolumn{7}{|c|}{ a. Dependent Variable: Motivasi Belajar } \\
\hline
\end{tabular}


yang diasuh dengan pola otoriter, akan membentuk anak menjadi pribadi yang kurang percaya diri, tidak mandiri, tidak kreatif, meskipun taat pada aturan. Berbeda lagi dengan anak yang diasuh dengan pola permisif, anak akan cenderung memiliki sikap dan perilaku bebas, tidak mandiri, menghalalkan segala cara dalam mencapai tujuan. Hal tersebut akibat orangtua terlalu mencurahkan toleransi sehingga anak cenderung hidup dengan keinginannya tanpa memperhatikan norma dan etika. Terakhir anak yang diasuh dengan pola acuh tak acuh. Anak dengan asuhan sepeti ini cenderung tidak memiliki rasa simpati dan empati terhadap lingkungan sekitar, bahkan menganggap hidupnya tak berarti.

Sementara motivasi belajar adalah salah satu prisip yang mesti ada dalam kegiatan belajar. Motivasi berarti daya pendorong, dalam hal ini adalah pendorong atau penggerak kehidupan belajar seseorang. Motivasi dapat mendorong seseorang untuk belajar, menentukan arah pembelajaran, sampai meyeleksi perbuatan belajar yang akan dilakukannya.

Motivasi utama adalah motivasi dalam diri, karena pada diri sendirilah seseorang mampu mengontrol atau menyeleksi perbuatannya. Namun, tidak semua orang memiliki motivasi dalam diri yang kuat, sehingga peranan motivasi dari luar menjadi sungguh berarti. Motivasi dari luar dapat diperoleh dari keluarga, sekolah, masyarakat dan alam. Keluarga yang merupakan lingkaran kecil dalam kehidupan seseorang, mestilah memiliki peranan yang besar terhadap kehidupan anggota keluargannya.

Dalam hal ini, pola asuh menjadi salah satu faktor yang mempengaruhi motivasi anak dalam belajar. Pola asuh tersebut dapat terindikasi dalam kontrol terhadap anak, komunikasi dengan anak, dan tuntutan terhadap kehidupan anak. Dengan adanya pola asuh yang tepat, diasumsikan motivasi belajar anak semakin baik. Namun, dalam usia remaja, anak memiliki faktor-faktor lain yang menjadi kepentingan dalam tugas perkembangan kehidupannya. Sehingga faktor orangtua, cenderung tidak lagi menjadi perhatian utama. Remaja dalam usianya, cenderung bereksistensi dalam kehidupan sosialnya. Sehingga berkemungkinan terdapat pengaruh yang besar dari kehidupan sosial remaja (seperti pergaulan dengan teman sebaya, media sosial, dan sebagainya) dalam kehidupannya. Dalam usia perkembangannya, remaja mestinya pun sudah mengenal sistem nilai, sehingga mereka dapat menentukan sikap dan perilaku yang sesuai dalam kehidupannya. Sehingga dengan demikian, faktor pola asuh orangtua menjadi tidak memiliki hubungan signifikansi yang sangat tinggi dalam memotivasi belajar anak dalam usia remaja.

\section{SIMPULAN DAN SARAN}

Simpulan dari penelitian dengan judul "Hubungan Pola Asuh Orangtua dengan Motivasi Belajar Remaja" ini adalah terdapat hubungan yang signifikan antara pola asuh orangtua dengan motivasi belajar remaja dengan kontribusi sebesar 18,8 \%, dimana sisanya peningkatan motivasi belajar dipengaruhi oleh faktor lain.

\section{DAFTAR RUJUKAN}

Djamarah, Syaiful B. (2014). Guru dan Anak Didik dalam Interaksi Edukatif. Jakarta: Rineka Cipta.

Djiwandoko, Sri Esti Wuryani. (2006). Psikologi Pendidikan. Jakarta: PT Grasindo.

Hurlock, E.B. (2012). Psikologi Perkembangan, Edisi 5. Jakarta: Erlangga.

Ladeni J . (2012) . Meningkatkan Motivasi Belajar Matematika Siswa dengan penerapan Model pembelajaran Kooperatif Tipe Think Talk Write. Jurnal Pendidikan Matematika. Retrieved December 12,2016, from http:/ejournal.unp.ac.id/student/index.html

Niaraki FR, Rahimi H. (2013).The impact of authoritative, permissive and authoritarian behavior of parents on self concept, psychological health and life quality. Europan online journal of natural and social sciences. 02(1):78-85.

Kordi A, Baharudin R.(2010). Parenting attitude and style and its effect on children's school achievements. International journal of psychological studies.02(2):217-22.

Israfil. (2015). Hubungan Pola Asuh Orang Tua Dengan Perkembangan Anak Usia Prasekolah. Seminar 
Psikologi Dan Kemanusiaan, 978-979. Retrieved from http://mpsi.umm.ac.id/files/file/175-179 Israfil.pdf

Miru, alimuddin s. (2009). Hubungan Antara Motivasi Belajar Terhadap Prestasi Belajar Mata Diklat Instalasi Listrik Siswa Smk Negeri 3 Makassar. Medtek, 1, 4-5. Retrieved from http://elektro.unm.ac.id/jurnal/Jurnal_MEDTEK_VOL.1. No. 1_2009/Alimuddin SM.pdf

Musaheri. (2007). Pengantar Pendidikan. Yogyakarta: IRCiSoD

Nasir, Z. M., \& Hamzah, Z. A. Z. (2014). Sikap Dan Motivasi Pelajar Terhadap Pembelajaran Bahasa Melayu. Procedia - Social and Behavioral Sciences, 134, 408-415. https://doi.org/10.1016/j.sbspro.2014.04.263

Purwanto, Ngalim. (2007). Psikologi Pendidikan. Bandung: Remaja Rosdakarya.

Santrock, John W. (2010). Psikologi Pendidikan. Jakarta: Kencana.

Sardiman, A.M. (2011). Interaksi dan Motivasi Belajar Mengajar. Jakarta: PT. Rajagrafindo Persada.

Sumantri Sumantri, Mulyani dan Nana Syaodih. (2007). Perkembangan Peserta Didik.Jakarta:Universitas Terbuka.

Uno, H. (n.d.). B. 2007. Teori Motivasi Dan Pengukurannya.

Uno, H. B. (2006). Perencanaan pembelajaran. Jakarta: Bumi Aksara, 61, 1.

Yusuf, S. (n.d.). LN. (2001). Psikologi Perkembangan Anak dan Remaja. Cetakan Kedua, Bandung: Remaja Rosda Karya.

Yusuf, S. (n.d.). LN. (2012 ). Teori motivasi dan pengukurannya.Jakarta: Bumi Aksara. 